\section{Determinants of Women Empowerment at Domestic and Non-domestic Issues: Evidence from Chapai Nawabganj District in Bangladesh}

\author{
Mosiur Rahman, Uzzal K. Karmaker and Abdur R. Mia
}

\begin{abstract}
This paper makes an attempt to investigate the determinants of women empowerment at domestic and non-domestic issues in Bangladesh by examining the situation prevailing in one particular area of Chapai Nawabganj district using the information from 500 ever married women within the reproductive span (15-49 years). Our study documented that, although a large percentage of women were enjoying empowerment at various domestic and non domestic related issues still it is not in a satisfactory level. Only 4.5\% women could take decision for child health care activities and 51.6\% could caste vote with their own decision and 59.0\% respondents could handled the daily expenditure for the family. Findings reveled that $79.7 \%$ respondent's expressed their opinion having freedom of movement outside the home without husband's permission and $83.0 \%$ respondents gave their opinion for equal right in education of son and daughter which seem to be a good indication regarding women's empowerment. From the logistic regression model considering decision-making power for household affairs as the dependent variable we saw that urban respondents, respondents living in combined family, having mass media facility have more decision making power regarding household affairs. The model also shows that as the level of
\end{abstract}

education of the respondents increases their decision making power also rises From the logistic regression model concerning decision-making power about casting vote the main contributing factors that have significant impact on women's decisions making power towards vote were found to be respondent's education, type of family, mass media exposure, age at marriage, daily household expenditure, freedom of movement, decision for household affairs and women's participation as representative.

Key words: household affairs, freedom of movement, caste of vote, daily expenditure, and logistic regression analysis.

\section{Introduction}

Bangladesh with 14 million populations is the eighth most populous countries in the world (BBS, 2003). The sex ratio is about 100.103 which mean that half of this nation population is females. But the gender inequality is so high in Bangladesh especially in the rural areas (Naznin Islam and Nahid Sultana, 2006). The universal fact of women in Bangladesh occupies a secondary and inferior position than that of men. In all aspect of life, education, work and employment, health and nutrition in short in most spheres of economic and social activities including the family women have limited opportunities (UNFPA, 2002). Women in Bangladesh have always been dependent on men and they have rarely had any opportunity to participate in social, political and economic decisions, though they contributed too heavily to the country's economy by their participation in agriculture alone with the household chores. Women seldom enjoy a decision making in the society or even in the house. They are under the control of male members in all stages of life (Mabud, M.A. and R. Akhter, 2003). Major family decision making power is vested on the male head of the family: father, husband or son. In case of sickness the decision to visit a doctor or to attend a hospital rests with the 
male. There are many other factors that stand as barrier to the effective care and management of women; i.e. their socio economic condition (Mahatab, Hajera and Prabha, M, 1999).

So now a day's women empowerment is a burning issue with regard to domestic and non-domestic issues. Thus, research that addresses the empowerment of women is seen as essential. Therefore, in view of the importance of this matter, an attempt has been made in this study to investigate the women's empowerment with respect to domestic and nondomestic issues in Bangladesh by examining the situation prevailing in one particular area Chapai Nawabganj district. The results of this study are expected to provide program and policy recommendations that will help to ensure improvement of women's status especially in domestic and non-domestic decision making power, both at the individual and community levels.

\section{Data Sources and Methodology}

The data were collected from a field survey conducted in the district of Chapai Nawabganj of Bangladesh. These data were collected from both, rural and urban areas of Chapai Nawabganj district from May 26 to July 29, 2007. Information was collected from 500 ever-married reproductive aged women (within age span 15-49) by interview method of them 250 were taken from rural areas and 250 from the urban areas respectively. Respondents were selected by purposive sampling method. For rural areas we had selected three villages under Baroghorian Union, and for urban areas we have selected Chapai Nawabganj thana of Chapai Nawabganj District. Data analytic methods envisaged in this paper were percentage distribution and binary logistic regression analysis.

\section{Results and Discussions}

\subsection{Determinants of Women's Empowerment at Domestic} Issues

To observe women's empowerment regarding domestic issues, we detected the three indicators as: decision-making power for household affairs, freedom of movement and daily household expenditure. Additionally, we also considered the decision-making power of women regarding child health care.

\subsection{Decision-making Power for Household Affairs}

Decision-making is the main theme of empowerment especially in the case of household head level (Mason, K.O.

and H.L. Smith. 2003). In a household, if both husband and wife are in head level, they would represent their decision equally. Obviously, housewives are the key decision maker about family welfare, but in our country, females are more vulnerable about their equal right. Table 1 shows the percentage distribution of respondent who could take decision for household affairs.

Table-1: Percentage distribution of respondent's decision making power for household affairs

\begin{tabular}{l|c}
\hline $\begin{array}{l}\text { Opinion of the } \\
\text { Respondent }\end{array}$ & Percentage \\
\hline Yes & 79.4 \\
No & 20.6 \\
\hline
\end{tabular}

The table indicates that about $79.4 \%$ women could take decision for household affairs. As majority of the women can take decision for household affairs so it can be pointed out 
from our study that women enjoyed empower in the sector of decision-making for household affairs.

\subsection{Freedom of Movement}

Freedom of movement is one of the most important indicators of domestic empowerment for the women. To upgrade a society, of course, freedom of movement is necessary because if women have freedom of movement then they will be able to participate in all spheres of developing activities. Such movement beyond the home may have important implications for exposure to information, development of interpersonal skills, increased self- confident and opportunities to take independent action (Syed $\mathrm{H}$ et al., 1993). But it is also necessary to see that the women should not be autocrat because it will hamper the social norms. So, compromise can be the major point, here. Husband will compromise with wife and vice versa would be expected.

Table-2: Percentage distribution of respondent's freedom of movement

\begin{tabular}{c|c}
\hline $\begin{array}{l}\text { Opinion of the } \\
\text { Respondent }\end{array}$ & Percentage \\
\hline Yes & 79.7 \\
No & 20.3 \\
\hline
\end{tabular}

The table indicates that, $79.7 \%$ of the respondent's expressed their opinion having freedom of movement outside the home without husband's permission. So, it can be said that a large percentage of women got freedom from their husband to move outside the home freely.

\subsection{Daily Household Expenditure}

Control over daily household expenditure by women means they have more dominating power over the family (Malhotra, Anju, Reeve Vanneman and Sunita Kishor, 1995). In general, women are more conscious about family welfare. So, they should have more dominating power over daily expenditure for the family. By this dominating power they can develop their family through the society. Although the women are conscious about family welfare but still they are to depend on husband because in most of the cases they are out of the access to money.

Table-3: Percentage Distribution of Respondent's Control over Daily Household Expenditure

\begin{tabular}{c|c}
\hline $\begin{array}{l}\text { Opinion of the } \\
\text { Respondent }\end{array}$ & Percentage \\
\hline Yes & 59.0 \\
No & 41.0 \\
\hline
\end{tabular}

Regarding daily household expenditure $41.0 \%$ women did not control over daily household expenditure and 59.0\% have controlled over daily household expenditure (Table-3). Hence it appears from the data that, women have dominating power over the family in respect of daily expenditure for the family

\subsection{Decision-making of power with regard to child health care}

It has often been argued that child health and investments in children are determined by intra-household resource allocation decisions, which are related to gender inequalities in the household. In families in which women play an important role in decision-making, the proportion of family resources devoted to children is greater than in families in which women play a less decisive role (Bruce, Lloyd, and Leonard, 1995; Blumberg, 1991). This notion of "maternal altruism" assumes that power in the hands of women will lead to better child outcomes (Mason, 1986). From the table 4 we see that, only $4.5 \%$ of respondent took care of their 
child according to their own decision and $95.5 \%$ of respondent took care of their child with others (mainly husband) decision.

Table -4: Percentage distribution of respondent's decisionmaking of taking children

\begin{tabular}{l|c}
\hline Decision-maker & Percentage \\
\hline Own & 4.5 \\
Others (Mainly & 95.5 \\
Husband) & \\
\hline
\end{tabular}

The result shows that, the women were much more behind than the men in decision-making of taking care of their children. So, to improve the social conditions and harmony, women should be given priority or at least equal power to make decision of child health care.

\subsection{Determinants of Women's Empowerment at Non- domestic Issues}

At the non-domestic level regarding women's empowerment we considered here only the following indicators: decision making power regarding casting vote in general election, opinion about men and women equal rights existing in the society, opinion about women's participation as a representative in the society and respondent's view about their daughter's education,

\subsubsection{Decision making power regarding casting vote in general election}

Decision about vote is one of the most important factors of women's empowerment. Since voting power is a democratic right, so, everybody should take the decision about vote with himself/herself uniquely (Kabeer N, 2001). But, we often see that women have been influenced by the decision of' their husbands, household head or similar male person. Consequently, women have no freedom to caste their vote with their own decision. Only women's empowerment can take an important role for the decision of casting vote willingly. Table 5 present the percentage distribution of respondents about their decision for casting vote.

Table -5: Percentage Distribution of Decision about Vote

\begin{tabular}{l|c}
\hline Decision-maker & Percentage \\
\hline Own & 51.6 \\
Husband & 44.5 \\
Household Head & 3.7 \\
Others & 0.2 \\
\hline
\end{tabular}

The table summarizes that, $51.6 \%$ respondents cast vote by their own decision. From the rest, 44.5, 3.7 and $0.2 \%$ respondents cast their vote by the decision of husband, household head and others respectively. We can say that, only half of the respondent's were enjoying freedom of exercise regarding their opinion about vote. So, it is necessary that this exercise should lift up to an optimum position.

\subsubsection{Opinion about Equal Rights Existing in the Society}

In order to increase the women empowerment, it is necessary to equalize the rights like educational enrollment, freedom of movement, labor force participation, equal wages for same work for men and women in the society (Abdus, S. and Shetty, N 2006). But we see in every sector that women are deprived and they are not getting the equal opportunity. Table 6 presents the percentage distribution of respondents view about the equal rights existing in the society. 
Table- 6: Percentage Distribution of Respondent's Opinion about the Equal Rights Existing in Society

\begin{tabular}{c|c}
\hline $\begin{array}{c}\text { Opinion of the } \\
\text { Respondent }\end{array}$ & Percentage \\
\hline Yes & 75.6 \\
No & 24.4 \\
\hline
\end{tabular}

From the study we observed that, most of the respondents agreed for existing equal rights in society. The percentage of them is $75.6 \%$.

\subsubsection{Opinion about Women's Participation as Representative}

Political right is one of the fundamental rights which influence empowerment of women (Basu A, 1996). Women's cheerfully participation as representative in various social welfare works consists of social rights. If women are becoming aware about their socio-politic rights and it helps them to empower.

Table- 7: Percentage Distribution of Respondent's Opinion about Women's Participation as Representative

\begin{tabular}{l|c}
\hline $\begin{array}{l}\text { Opinion of the } \\
\text { Respondent }\end{array}$ & Percentage \\
\hline Yes & 87.9 \\
No & 12.1 \\
\hline
\end{tabular}

From the table we see that $87.9 \%$ of the respondent expressed their opinion in favor of women's participation as a representative in the society. So, we can say that, women awareness has improved and there exists a positive empowering environment.

\subsubsection{Respondent's View about their Daughter's Education}

Women's education is one of the most important factors of the development of any nation because no nation can prosper without education specially mother's education and it is also called the backbone of nation (Amin S.N. Selim and Kamal $\mathrm{N}$, 2006). Table 8 shows the percentage distribution of respondents who expressed their positive view about daughter's education. From the study we see that, the maximum, $83.0 \%$ respondents gave their opinion for equal right in education of son and daughter. The rest, 9.4\% respondents were agreed for daughter's education less than son and the remaining $7.0 \%$ were agreed for daughter's education more than son respectively.

Table-8: Percentage Distribution of Respondent's View about their Daughter's Education

\begin{tabular}{l|c}
\hline $\begin{array}{l}\text { Opinion of the } \\
\text { Respondent }\end{array}$ & Percentage \\
\hline Equal to son & 83.0 \\
More than son & 7.0 \\
Less than son & 9.4 \\
Basis of \\
daughter's ability & 0.6 \\
\hline
\end{tabular}

Factors Affecting of the Determinants of Women's Empowerment at Domestic and Non-domestic Issues: Logistic Regression Analysis

In earlier findings regarding women's empowerment at domestic and non-domestic issues we have tried to understand the nature of women's empowerment by using different statistics, mainly by percentages. Now, we have 
employed a powerful statistical technique like logistic regression. In the present study, two logistic regression models which have been fitted to the data to identify the factors affecting women's empowerment at domestic and non-domestic issues were considered. The first model considered decision-making power for household affairs as the dependent variable which we dichotomized by assessing 1 , if the respondents have the decision making power for household affairs and 0 for otherwise. The second model considered decision-making power about casting vote as the dependent variable which we dichotomized by assessing 1 , if the respondents was the decision maker to cast their own vote and 0 , for otherwise.

Table 9 gives the estimates of logistic regression coefficient ( $\beta)$ and relative odds calculated for each category for corresponding independent variables for the model on decision-making power for household affairs. From table-9 it appears that place of residence has strong and positive net significant impact on decision-making power for household affairs, urban respondents have approximately 6.0 times more decision making power regarding household affairs than their rural counterparts.

Table-9: Logistic regression estimates of decision-making power of married women for household affairs on some selected socio-demographic characteristics

\begin{tabular}{l|c|l}
\hline Characteristics & Coefficient of $\boldsymbol{\beta}$ & $\begin{array}{l}\text { Odds ratio } \\
\operatorname{Exp}(\boldsymbol{\beta})\end{array}$ \\
\hline $\begin{array}{l}\text { Place of Residence } \\
\text { Rural }^{\text {Ref) }}\end{array}$ & - & 1.000 \\
Urban $^{\text {Respondents }}$ & 1.778 & $5.915^{* * *}$ \\
Education $_{\text {Illiterate }}^{\text {(Ref) }}$ & & \\
Primary & - & 1.000 \\
\hline
\end{tabular}

\begin{tabular}{|c|c|c|}
\hline $\begin{array}{l}\text { Secondary } \\
\text { Higher }\end{array}$ & 1.971 & $7.178^{*}$ \\
\hline $\begin{array}{l}\text { Husband's } \\
\text { Education } \\
\text { (Illiterate) }^{(R e f)} \\
\text { Primary } \\
\text { Secondary } \\
\text { Higher }\end{array}$ & $\begin{array}{c}- \\
1.662 \\
2.034 \\
3.159\end{array}$ & $\begin{array}{l}1.000 \\
1.190 \\
1.131^{* *} \\
2.042^{* * *}\end{array}$ \\
\hline $\begin{array}{l}\text { Type of Family } \\
\text { Nuclear }^{(\mathrm{Ref})} \\
\text { combined }\end{array}$ & $\begin{array}{c}- \\
0.799 \\
\end{array}$ & $\begin{array}{l}1.000 \\
2.224^{* *}\end{array}$ \\
\hline $\begin{array}{l}\text { Religion } \\
\text { Islam }^{(\mathrm{Ref})} \\
\text { Others } \\
\end{array}$ & $\begin{array}{c}- \\
0.701 \\
\end{array}$ & $\begin{array}{l}1.000 \\
2.015 \\
\end{array}$ \\
\hline $\begin{array}{l}\text { Per Capita Income } \\
\text { (yearly) } \\
<15000^{\text {(Ref) }} \\
15000-30000 \\
>30000\end{array}$ & $\begin{array}{c}- \\
1.395 \\
1.152\end{array}$ & $\begin{array}{l}1.000 \\
1.1614 \\
1.039\end{array}$ \\
\hline $\begin{array}{l}\text { Age at marriage } \\
<15^{\text {(Ref) }} \\
15-20 \\
20 \text { and above } \\
\end{array}$ & $\begin{array}{c}- \\
3.556 \\
1.637 \\
\end{array}$ & $\begin{array}{l}1.000 \\
5.141^{*} \\
2.948^{* * *}\end{array}$ \\
\hline $\begin{array}{l}\text { Having mass } \\
\text { media exposure } \\
\mathrm{No}^{(\mathrm{Ref})} \\
\mathrm{Yes}\end{array}$ & $\overline{-}$ & $\begin{array}{l}1.000 \\
1.197^{* *}\end{array}$ \\
\hline
\end{tabular}

It is also observe that as the level of education of the respondents increases their decision making power also rises. Higher educated women have at least 7.1 times more power than the illiterate women. The same result is observed in case of husband education. Respondent's type of family has 
significant effects on decision-making. The relative's odd ratio is found to be 2.224 indicating respondents living in combined family 2.224 times more likely to have decision power of household affairs than the respondents living in nuclear family.

Age at marriage is one of the important factors that have positive significant effect on decision-making power for household affairs (Amin S.N. Selim and Kamal N 2006). The result shows that, women who married within the age group 15- 20 years were 5.141 times more likely to have decision power for household affairs than the women whose age at marriage lies below 15 years. The results show that, respondents having per capita yearly income Tk. (1500030000) was 1.1614 times more likely to make decision for household affairs than that of respondents having per capita yearly income below Tk. 35000.Having mass media exposure in the household of married women is an important variable. The relative odds ratio was found to be 1.197 times indicating higher prevalence of decision-making power among married women who have mass media exposure in the household as compared with those having no such facility. The possible fact is that having mass media in the household may improve the power of decision-making among married women. This is why; mass media may play an important role to reach the motivational massages specially the decision-making of house hold affairs to the married women.

Table 10 gives the estimates of logistic regression coefficient ( $\beta)$ and relative odds calculated for each category for corresponding independent variables for the model concerning respondent's decision-making power about casting their own vote. From the result of logistic regression analysis, it appears that respondent's education has strong and positive net significant effects on decision-making power about vote. For this study we see that, respondents with higher education were 3.030 times more likely to make their own decision about casting vote than the illiterate respondents.

Table -10: Logistic regression estimates of decision-making power of married women about casting their own vote on some selected characteristics

\begin{tabular}{|c|c|c|}
\hline Characteristics & Coefficient of $\beta$ & $\begin{array}{l}\text { Odds } \\
\text { ratio } \\
\operatorname{Exp}(\beta)\end{array}$ \\
\hline $\begin{array}{l}\text { Place of Residence } \\
\text { Rural }^{(\text {Ref })} \\
\text { Urban }\end{array}$ & $\begin{array}{c}- \\
0.344\end{array}$ & $\begin{array}{l}1.000 \\
1.410\end{array}$ \\
\hline $\begin{array}{l}\text { Respondent's Education } \\
\text { Illiterate (Ref) } \\
\text { Primary } \\
\text { Secondary } \\
\text { Higher }\end{array}$ & $\begin{array}{c}- \\
0.244 \\
0.290 \\
1.109\end{array}$ & $\begin{array}{l}1.000 \\
1.267 \\
1.336^{*} \\
3.030^{* * *}\end{array}$ \\
\hline $\begin{array}{l}\text { Respondent's Occupation } \\
\text { Paid jobs (Ref) } \\
\text { Non-paid jobs }\end{array}$ & $\begin{array}{c}- \\
-0.222\end{array}$ & $\begin{array}{l}1.000 \\
0.895\end{array}$ \\
\hline $\begin{array}{l}\text { Type of Family } \\
\text { Nuclear }^{(\text {Ref })} \\
\text { Combined }\end{array}$ & $\begin{array}{c}- \\
-0.713\end{array}$ & $\begin{array}{l}1.000 \\
0.490^{* * *}\end{array}$ \\
\hline $\begin{array}{lll}\text { Having mass media } \\
\text { exposure } & & \\
\text { No }{ }^{(R e f)} & & \\
\text { Yes } & & \end{array}$ & $\begin{array}{c}- \\
1.065\end{array}$ & $\begin{array}{l}1.000 \\
1.937^{* *}\end{array}$ \\
\hline
\end{tabular}




\begin{tabular}{|c|c|c|}
\hline $\begin{array}{l}\text { Age at Marriage } \\
<15^{\text {(Ref) }} \\
15-20 \\
20 \text { and above }\end{array}$ & $\begin{array}{c}- \\
0.040 \\
0.623\end{array}$ & $\begin{array}{l}1.000 \\
1.041^{*} \\
1.865^{* *}\end{array}$ \\
\hline $\begin{array}{ll}\text { Daily } & \text { Household } \\
\text { Expenditure } & \\
\text { No }{ }^{\text {(Ref) }} & \\
\text { Yes }\end{array}$ & $\begin{array}{c}- \\
0.85\end{array}$ & $\begin{array}{l}1.000 \\
2.348^{* * *}\end{array}$ \\
\hline $\begin{array}{l}\text { Freedom of Movement } \\
\text { No }{ }^{\text {(Ref) }} \\
\text { Yes }\end{array}$ & $\begin{array}{c}- \\
1.501\end{array}$ & $\begin{array}{l}1.000 \\
1.606^{* *}\end{array}$ \\
\hline $\begin{array}{l}\text { Decision for Household } \\
\text { Affairs } \\
\text { Representative } \\
\text { (No) }^{\text {(Ref) }} \\
\text { Yes }\end{array}$ & $\begin{array}{c}- \\
1.324\end{array}$ & $\begin{array}{l}1.000 \\
3.760^{* * *}\end{array}$ \\
\hline $\begin{array}{l}\text { Women's Participation as } \\
\text { Representative } \\
\text { (No) }^{(\text {Ref })} \\
\text { Yes }\end{array}$ & $\begin{array}{c}- \\
1.324\end{array}$ & $\begin{array}{l}1.000 \\
3.760^{* * *}\end{array}$ \\
\hline
\end{tabular}

Note: Here $($ Ref $)=$ reference category and $*, * *$ and $* * *$ indicates $\mathrm{p}<\mathbf{0 . 0 5}, \mathrm{p}<\mathbf{0 . 0 1}$ and $\mathrm{p}<\mathbf{0 . 0 0 1}$

Respondent's who were involved in non-paid jobs were 0.895 times less likely to have power on decision-making about vote than the respondents who were involved in paid jobs (service, business etc.). The result shows that, urban women were 1.410 times more likely to have decision making power about casting their own vote than rural women. With regard to respondent's type of family the relative odd ratio is found to be 0.490 indicating respondents lived in combined family were 0.490 times less likely to make decision about their own vote than the respondents who lived in nuclear family. The result shows that, women who married at 15-20 years of age were 1.041 times more likely to make decision about vote than the women whose age at marriage lies below the of 15 years. Having radio and television in the household of married women is an important variable. Here, it is contributed significant effect on decisionmaking about vote. The relative odds ratio is found to be 1.937 indicating higher prevalence of decision-making about vote among married women who have radio or television in the household as compared with those having no such facility. Control over daily household expenditure by women has also strong and positive significant association with decision-making about vote, In this study we observed the result that, the respondents who have controlled over daily household expenditure were 2.348 times more likely to make decision about their own vote than the respondents who did not have control over daily household expenditure. Respondent's decision for household affairs is an important variable; it contributes significant association with decisionmaking about vote. The relative odds ratio is found to be 3.760 indicating 3.760 times more likely to make decision about vote among the respondents who could make decision for household affairs as compared with those have no such decision- making power. The result shows that, the respondents who were enjoy freedom of movement outside the home were 1.606 times more likely to make decision about casting their own vote than who were not permitted for freely movement outside their home.

\section{Conclusions}

The study showed that $79.4 \%$ women can took decision for household affairs. As majority of the women can took 
decision for household affairs so it can be pointed out from our study that women enjoyed empower in the sector of decision-making for household affairs. It was also found that $79.7 \%$ of the respondent's expressed their opinion having freedom of movement outside the home without husband's permission. Around $59.0 \%$ respondent's handled the daily expenditure for the family. Study showed that 95.5\% respondents have no decision making power regarding child care which revealed that, women were much more behind than the men in decision-making of caring children. With regard to non-domestic related issues, $51.6 \%$ respondent's caste their vote by their own decision and the rest of 44.53 .7 and $0.2 \%$ respondent's caste their vote by the decision of husband, household head and others respectively. From the study we also observed that, most of the respondents agreed for existing equal rights in society. About $83.0 \% \mathrm{t}$ respondents gave their opinion for equal right in education of son and daughter. The rest, 9.4 and $7.0 \%$ respondents were agreed for daughter's education less than son and more than son respectively. From the logistic regression model considering decision-making power for household affairs as the dependent variable we saw that place of residence has strong and positive significant impact on decision-making power for household affairs, urban respondents approximately 6.0 times more took the decision regarding household affairs than their rural counterparts. It is also observe that as the level of education of the respondents increased their decision making power also increased. Respondent's living in combined family 2.224 times more likely to have decision power of household affairs than the respondents living in nuclear family. Age at marriage was found as one of the important predictor on decision-making power for household affairs. The result shows that, women who married at 15- 20 years of age were 5.141 times more likely to have decision power for household affairs than the women whose age at marriage lies below 15 years. It was also found that having mass media facility in the household indicates higher prevalence of decision-making among married women as compared with those having no such facility. From the logistic regression model concerning decision-making power about casting vote as the dependent variable the main contributing factors that have significant impact on women's decisions making power towards casting vote were found to be respondent's education, type of family, mass media exposure, age at marriage, daily household expenditure, freedom of movement, decision for household affairs, opinion about women's participation as representative.

From the study we found that although a large percentage of women were enjoying empowerment at various domestic and non domestic related issues still it is not in a satisfactory level. Still much work has to be done in this arena to attain more success in improving women's status of our country. In the light of the above discussions some policy implications have been recommended: provide education and training that enable women to catch up and adapt to changing economic conditions. Provide universal primary education for both girls and boys and parents should give value to their daughters equally as sons; enable women to exercise their rights to control their own fertility and their right to make decision concerning reproduction, discrimination and violence; increase gender equality and equal opportunities for women in all spheres of employment; the government should create more job opportunities for women which would enable them to have further their lives in different dimensions and have more control power in the home and society; Create awareness among the married women about the decision making power regarding freedom of movement, own health care and access to economic resources through special information, education and communication campaigns which may develop, the socio-cultural conditions of the country. 
Conflict of Interest: the author declare that he has no conflict of interest

Acknowledgement: I would like to thank the women and other research assistants who participated in this study.

\section{References}

Abdus, S. \& Shetty, N. (2006). Empowering the powerless: The Grameen Bank experience, Journal of Development Communication, 17, (2). 70-76.

Amin, S. N. Selim \& Kamal, N. (2006). Causes and consequences of early marriage in Bangladesh, Population Council, Dhaka, Bangladesh

Bangladesh Bureau of Statistics (BBS) (2003). Statistical Pocket Book of Bangladesh. Statistics Division. Ministry of Planning, Dhaka.

Basu, A. (1996). Girls' schooling, sutonomy and fertility change: what do these words mean in South Asia? Women's Autonomy and Fertility Change in South Asia, pp. 48-71.Sage Publications, India

Blumberg, R.L., ed. (1991). Gender, family and economy: The triple overlap. Newbury Park, California: Sage Publications.

Bruce, J., C. Lloyd, and A. Leonard, (1995). Families in focus: New perspectives on mothers, fathers and children. New York: The Population Council.

Kabeer, N. (2001). .Conflicts over Credit: Re-evaluating the empowerment potential of loans to rural women in Bangladesh, World Development, 29, 63-84.
Mabud, M.A. \& Akhter, R. (2003). Recent shift in Bangladesh’s population policy and programme strategies: prospects and risks in Bangladesh”, in population momentum, consequences and policy implications .Centre for Policy Dialogue (CPD), Pathak Shamabesh Bangladesh

Mahatab, Hajera \& Prabha, M. ( 1999). Rural Women: Bangladesh perspective. Journal of Economic and Social Council, Vol. 8 No. 2.

Malhotra, Anju, Reeve Vanneman \& Sunita Kishor (1995). Fertility, dimensions of patriarchy, and development in India." Population and Development Review, 21:281-305

Mason, K.O. (1986). The status of women: Conceptual and methodological issues in demographic studies. Sociological Forum 1(2): 284-300.

Mason, K.O. and H.L. Smith. (2003). Women's empowerment and social context: Results from five Asian countries. Washington, D.C.: The World Bank.

Naznin Islam and Nahid Sultana (2006). The Status of Women in Bangladesh: Is the Situation Really Encouraging? Research Journal of Social Sciences, 1(1): 56-65

Sayed, H. et al. (1993). Fertility and Family Planning in Egypt 1984. Columbia, Maryland: National Population Council (Cairo) and Westinghouse Public Applied Systems.

UNFPA (2002). Women's empowerment and reproductive health. Links throughout the life cycle, published as part of UNFPA's advocacy booklet series, March 2002. 